\title{
Profiles of the Editorial Team
}

CLARA FISCHER works in the areas of feminist philosophy, social and political theory, and gender politics, with a particular focus on feminist pragmatism and theories of emotion and embodiment. She is an EU Marie Sklodowska-Curie Fellow at the Centre for Gender, Feminisms, and Sexualities, and Co-director of the Dewey Studies Research Centre at University College Dublin. Dr. Fischer is the author of Gendered Readings of Change: A Feminist-Pragmatist Approach (Palgrave MacMillan, 2014), and co-editor of Irish Feminisms: Past, Present and Future (Arlen House/Syracuse University Press, 2015), New Feminist Perspectives on Embodiment (Palgrave MacMillan, 2018), and the forthcoming Philosophical Perspectives on Contemporary Ireland (Routledge). She has published widely in the leading journals in her area of expertise, including in Hypatia, Signs: Journal of Women in Culture and Society, and Feminist Review. She is the guest editor of a special issue of Hypatia on "Gender and the Politics of Shame" (2018) and co-editor of a special issue of Contemporary Pragmatism on "John Dewey and Critical Philosophies for Critical Political Times" (2019). She is the PI on EU Horizon2020 project, GENDEMOTION: The Gendered Politics of Emotion in Austerity Ireland. Dr. Fischer sees Hypatia as a go-to source for feminists seeking high-quality, reliable feminist scholarship, and Hypatia Reviews Online as an invaluable extension of this. They form a vital resource for feminists seeking accurate and enlightening pieces on cutting-edge feminist research. Dr. Fischer looks forward to taking on the role of book review co-editor for $\mathrm{HRO}$ in January 2020.

SARAH LACHANCE ADAMS is Distinguished Professor and Director of the Florida Blue Center for Ethics at the University of North Florida. She specializes in ethics, existential phenomenology, and feminist philosophy. Her books include one monograph: Mad Mothers, Bad Mothers, and What a "Good" Mother Would Do: The Ethics of Ambivalence (2014); and several anthologies, including New Philosophies of Sex and Love (2016); Coming to Life: Philosophies of Pregnancy, Childbirth, and Mothering (2012); and The Maternal Tug: Ambivalence, Identity, and Agency (2020). Her works investigate the intersections of lived experience and social structures, existential dissonance, and errors and conflict in self-understanding. She sees her work for Hypatia as an expression of gratitude to the scholars of feminist philosophy.

BONNIE MANN is Professor of philosophy at the University of Oregon and specializes in continental feminist philosophy, working between feminist phenomenology,

Hypatia vol. 34, no. 3 (Summer 2019) (C) by Hypatia, Inc. 
poststructuralism, and materialist feminism. Her current research thematizes the imaginary and affective dimensions of gender stratification, especially as they are mobilized in nationalism and other broad political phenomena, while remaining tied to the visceral and personal dimensions of gendered existence. She is an expert on the work of Simone de Beauvoir and Judith Butler. She is currently on the APA Committee on LGBTQ People in the Profession. Her most significant publications include: Sovereign Masculinity: Gender Lessons from the War on Terror (Oxford University Press, 2014), and Women's Liberation and the Sublime: Feminism, Postmodernism, Environment (Oxford University Press, 2006). Her most widely read and taught article is "Creepers, Flirts, Heroes and Allies: Four Theses on Men and Sexual Harassment" (2012). Editing Hypatia is another way to do the work of advocating for feminist philosophy as a central and legitimate area of philosophical inquiry, and for the transformation of the discipline.

ERIN MCKENNA is Professor of philosophy at the University of Oregon and works in American philosophy with a special focus on feminist pragmatism and ecofeminism. A former president of the Society for the Advancement of American Philosophy (SAAP), she is an expert in the areas of animal ethics, ecofeminism, the work of Charlotte Perkins Gilman, Alain Locke, and the social and political thought of John Dewey. Her books include: Livestock: Food, Fiber, and Friends (University of Georgia Press, 2018); Pets, People, and Pragmatism (Fordham University Press, 2013); American Philosophies, co-authored with Scott L. Pratt (Bloomsbury, 2015), and The Task of Utopia: A Pragmatist and Feminist Perspective (Rowman and Littlefield, 2001). She has edited several books as well. Among her numerous journal articles and book chapters, her contributions to Feminist Interpretations of John Dewey (Penn State University Press, 2002) and Feminist Interpretations of William James (Penn State University Press, 2015) may be most relevant here. She is a former chair of the APA Committee on the Status of Women. She sees her role as part of the editorial team for Hypatia as an extension of her scholarly and professional commitments to create a pluralistic and inclusive approach to philosophy that honors differences while also seeking to find common ground.

ELI PORTELLA is a doctoral candidate in philosophy at the University of Oregon and the current editorial assistant for Hypatia. Broadly speaking, her research interests include social and political philosophy, critical theory, and the philosophy of history. Her dissertation research focuses on the relationship between critical theory and the philosophy of history, with an emphasis on the philosophical complexities of historically situated critique. A recipient of the Tinker Field Research Grant in 2017, her research in the national archives of Havana focused on the history of international, decolonial leftist solidarity and the Federación de Mujeres Cubanas. With specific reference to feminist philosophy, her research has focused on the traditions of Marxist and materialist feminisms, including social reproduction theory. Her current research in feminist philosophy concerns the relationship between the framework of "epistemic injustice" (especially "hermeneutical injustice") and the tradition of ideology critique. 
Her work appears in Rethinking Marxism, Theoria 83 Praxis, Philosophy Today (forthcoming), and the Journal of the Philosophy of History (forthcoming). Eli's interest in working for Hypatia is motivated by a desire for collective work and critical self-reflection within the feminist community.

KAJA JENSSEN RATHE is a doctoral candidate in philosophy at the University of Oregon. Her work focuses on immigration and privacy within the field of critical phenomenology. She is the managing editor of Hypatia Reviews Online. She is also a co-editor and co-founder of Puncta - Journal of Critical Phenomenology. She appreciates the opportunity to combine philosophical research with editorial work and believes book reviews are an underestimated genre. In texts like book reviews, writers get a chance to engage with someone else's thinking in a different way than in a standard academic article. She is excited that Hypatia Reviews Online is accessible online for everyone who is interested in feminist philosophy since philosophy-especially feminist philosophy-belongs just as much outside the university as within.

CAMISHA RUSSELL is Assistant Professor of philosophy at the University of Oregon and works in critical philosophy of race with a particular strength in bioethics. She is a current member of the APA Committee on the Status of Blacks in Philosophy, and a former member, then chair, of the Society for Phenomenology and Existential Philosophy (SPEP) Committee on Racial and Ethnic Diversity. She is also a member of the current Hypatia task force. Her first book, The Assisted Reproduction of Race (Indiana University Press, 2018) considers the role of the race idea in practices surrounding assisted reproductive technologies and argues for the benefits of thinking of race itself as a technology. Other recent publications include "Rights-holders or Refugees? Do Gay Men Need Reproductive Justice?" in Reproductive Biomedicine $\mathcal{E}$ Society Online (2018), a chapter on eugenics in The Routledge Companion to the Philosophy of Race (2017), "Questions of Race in Bioethics: Deceit, Disregard, Disparity, and the Work of Decentering" in Philosophy Compass (2016), and "The Race Idea in Reproductive Technologies: Beyond Epistemic Scientism and Technological Mastery" in the Journal of Bioethical Inquiry (2015). She is a committed philosophical pluralist and a meliorist, who believes genuinely, if naively, in working within institutions to bring about transformation. She has been deeply influenced by a number of articles by women of color published in the pages of Hypatia and sees the complex challenges of co-editing the journal as an act of gratitude toward those scholars and the ones to come.

JOAN WOOLFREY is Professor of philosophy at West Chester University of Pennsylvania. She has been interim book review co-editor of Hypatia Reviews Online since July 2017 (with Simon Ruchti from WCU through Spring 2018) and is now working as book review co-editor with Erin McKenna. In addition, she is co-editor of volumes 33-35 (2016-2018) of Social Philosophy Today. Her long-term interest in the intersection of virtue ethics and feminist philosophy has most recently inspired articles on the concept of hope, and a forthcoming chapter on "The Virtue of Maternal 
Ambivalence" in The Maternal Tug: Ambivalence, Identity, and Agency, edited by Sarah LaChance Adams, Tanya Cassidy, and Susan Hogan. She received her PhD from the University of Oregon in 1996 and is happy to be able to assist Hypatia during the transition to the Oregon team. Having been a member of Hypatia's "local advisory board" from 2013 to 2017, she has felt more and more connected to the journal over time. Hypatia Reviews Online is a rich resource for feminist philosophers, and she is honored to be a part of the team working to create and maintain this open access division of Hypatia. In these volatile times, such resources are ever more important. And $\mathrm{HRO}$ is a resource (as is the journal itself) that is not imitated elsewhere. The field of feminist philosophy would be significantly poorer without it.

ROCÍO ZAMBRANA is Associate Professor at the University of Oregon, and her work examines conceptions of critique in various philosophical traditions, including Hegel, Marx, Frankfurt School critical theory, Marxist feminism, decolonial thought and decolonial feminisms, and Latinx, Latin American, and Caribbean feminisms. Her current work centers the category of coloniality, considering the articulation and deployment of race/gender as crucial to the development and resilience of capitalism. She is the author of Hegel's Theory of Intelligibility (University of Chicago Press, 2015), and Colonial Debts: The Case of Puerto Rico (under contract, Duke University Press). She is a columnist for 80 grados (San Juan, Puerto Rico), where she has written about feminist interventions concerning debt, violence, and austerity. She has been a member of the University of Oregon's Center for the Study of Women in Society's Women of Color Group since 2010. She has also served on the APA's Committee for Hispanics, the Society for Phenomenology and Existential Philosophy's Committee for the Status of Women, and Philosophy in an Inclusive Key Summer Institute (PIKSI). She served as editor, then chief and managing editor, and finally senior consulting editor for the Graduate Faculty Philosophy Journal from 2003-2010. She aspires to editorial practices that lead to the publication of essays and musings that can meaningfully name experiences of the lives of philosophy's practitioners. 